\title{
The Symbolism of Water in Early Christian Baptisteries
}

\section{Olof Brandt}

\begin{abstract}
The symbolism of water in the Early Christian baptisteries was not expressed in the architecture of the building but rather in its decoration. This article illustrates the references to water in the sculptures and inscriptions of the fourth and fifth-century phases of the Lateran baptistery in Rome. This decoration shows that the water was a symbol of both life and death: the death of the sinner and the life of God, to which baptism gave access.
\end{abstract}

Olof Brandt, Istituto Svedese di Studi Classici, Via Omero 14, I-00197 Roma, Italy

Key words: Architecture, baptism, baptisteries, deer, lamb, sculptures, symbolism, water.

An interesting example of the deep symbolic meaning which can be ascribed to water is the Early Christian baptistery, built as an architectural setting for Christian initiation through the ritual bath of baptism. The preserved Early Christian baptisteries, about 500 in all, were mainly built in the fourth, fifth and sixth centuries in Italy, Greece, Croatia, North Syria, Palestine and Tunisia. These buildings consist of a simple or a monumental room or hall with a basin, the font, where the initiation of new believers took place through the ritual bath of baptism in solemn ceremonies during the Vigils of Easter and Pentecost (for Early Christian baptism, see: Saxer 1988). Baptism was normally the prerogative of the bishop, which is why most baptisteries are found close to churches identified as cathedrals or bishop churches.

The symbolic value of the water of baptism was deeply felt already in the earliest Christian generations (see Saxer 1988 and Finn 1992): the Didaché of the late first century $\mathrm{AD}$ states that it is preferable to baptize in "living water", that is, in running water (Didaché 7.1-3. In: SC 248. On the Didaché, see: Saxer 1998). The expression "living water", discussed long ago in a famous article by Theodor Klauser (Klauser 1939), shows that the water itself was seen as an important symbol of the life of God to which the Christian initation gave access, and which is a reminder of the promise of Jesus that whoever believes in Him will have within him a source of "living water" (John 4:14; 7:38). The "source of living water" was denoted as God himself already in the seventh century BC by the prophet Jeremiah (Jer 2:13). Still in the fifth century AD, God the Father was 
often described as a source by Christian writers, like in the pre-baptismal catecheses of Cyrillus of Jerusalem (Cyrillus of Jerusalem, Catechesis 18,29. In: PG 33, 1050).

However, only centuries later this symbolism was reflected in architecture and art, since, interestingly enough, the earliest preserved baptisteries were built several centuries after the beginning of Christianity. This is of course also true of Christian architecture in general, which seems to have begun first in the third century. Before that time, the Christian communities probably were so small that normally they could meet in private houses. It was first in the third century that the communities became so big that it was necessary to adapt private houses on a permanent basis or even build completely new buildings for the liturgical gatherings, which became the standard procedure from the fourth century and on.

The origin and development of the Early Christian baptisteries can now be followed thanks to the recent catalogue of all known baptisteries published by Sebastian Ristow (Ristow 1998), which replaces the outdated catalogue of A. Katchatrian (Katchatrian 1980). The earliest known baptistery wa a small rectangular basin built against a wall in a house-church in Dura Europos in the 230s (Dura 1967). All the other known Early Christian baptisteries were built after the beginning of the fourth century and primarily in the fifth and sixth centuries. While the Dura baptistery was small and very simple, the baptisteries which were created from the fourth century and on were often monumental and important masterpieces of Late Antique architecture, although simpler baptisteries were common also in later periods in smaller and poorer churches. The later baptisteries could be made more monumental simply because Christianity was expanding among the richer upper classes and the Church had more money to build churches and baptisteries, thanks to imperial or private sponsorship or donations to the Church. Probably not only the Dura baptistery was built before the end of the great persecution of Diocletian. However, it is probable that the same persecution destroyed several churches and baptisteries built throughout the Roman world during the periods of peace in the third century before the persecutions of the middle of the century, and between that and the great persecution under Diocletian from the end of the third to the beginning of the fourth century.

The Early Christian baptisteries were designed for the baptism of adults, which was performed in a circular or polygonal basin or font, about one meter deep, in which the baptized person stood with the water up to his waist while being baptized by a bishop or priest. Many simpler baptisteries were only rectangular or square rooms, just like the old Dura baptistery, with a font in the middle, but more monumental baptisteries could be octagonal, especially in northern Italy and southern France, where they often were internally octagonal and externally square (Guyon 2000).

Baptistery architecture was created in this period between the third and fifth centuries AD. However, baptisteries should not only be seen in the context of Early Christian architecture. Early Christian baptisteries belong to a wider architec- 
tural universe of water architecture which was particularly dynamic in this period. The modern visitor to ancient Roman sites may not always be aware of how late most of the famous baths were built, and that many of them belong to the same period when the first monumental Christian baptisteries were created. Late Antiquity was a period when the meeting between people and water inspired many different kinds of important architectural creations in the Roman world. These range from the most famous Roman baths, those of Caracalla and of Diocletian in Rome, built in the early third and fourth centuries (for these and other Roman baths, see the catalogue in Nielsen 1990), to the many fourth-century nymphaea in private domus which can be admired still today in cities like Ostia (Neuerburg 1960 and Farrar 1996), and to the basins for water shows (kolymbéthrai) which were installed in the orchestras of many Greek and Roman theatres. Surely it was not a coincidence that this period also inspired the creation of monumental architectural settings for the bath of Christian baptism. I have tried to sketch the relationship between Late Antique water architecture and the creation of the baptistery architecture in an earlier paper (Brandt 2001).

The word "baptistery" itself shows this close relationship with other water architecture. It derives from the Greek "baptistérion" Latinized to "baptisterium", and it is the term commonly used today for the buildings for Christian baptism, though it originally means simply a place where one can dip in water - baptizein (from Pliny, Ep. 2.17.11; 5.6.25). Usually, this word indicated a basin or piscina, more rarely the room or building in which it was placed. In the fourth and fifth centuries, "baptisterium" could mean both a Christian building and a certain part of a Roman bath. In AD 470 Sidonius used it when referring to his private bath (Sidonius, Ep. 2.2.8). A Christian baptistery was a particular place within this larger group of buildings. For this reason, the precise meaning was often made clearer by adding another word: "the baptistery of the basilica, the church of the baptistery, the temple of the baptistery, the hall of the baptistery" (baptisteria basilicae, ecclesia baptisterii, templum baptisterii, baptisterii aula). A Christian baptistery was identified as such by its context and decoration, not by its fundamental shape, although sometimes also the decoration may be ambiguous, as in the case of some inscriptions which do not state clearly if they refer to baptisteries, baths or nymphaea (Cuscito 2001:441f).

Although Early Christian baptisteries had many different shapes and no two baptisteries are identical, it is evident that some fundamental shapes had more success, especially the octagonal hall with a font in the centre of the room. Many scholars have discussed why the Earliest Christian buildings - not only the baptisteries but also the basilicas - were built already from the beginning in a few fundamental shapes which were then immediately copied and spread throughout the Roman world. Was there a symbolic meaning behind the shape of the buildings? The octagonal baptisteries have been seen as imitations of both baths and mausolaea, which would fit very well with traditional interpretations of Christian baptism as a death from sin through a cleansing ritual bath. From the first and 
important article by Styger (Styger 1933) this has also been the prevailing opinion. However, it is difficult to trace the origin of the octagonal baptisteries to any specific building category because similar octagonal halls were built in the early fourth century also as vestibules or dining rooms in the Imperial palaces, making it hard to see any particular symbolism in the octagonal shape. Octagonal rooms were simply very popular in Late Roman architecture. It is true that symbolic interpretations were made by Late Antique Christians. Ambrose, the bishop of Milan in the second half of the fourth century, wrote in an inscription (ILCV 1841 ) in the octagonal baptistery of his cathedral that the octagonal shape was a reminder of the eighth day of Creation which was Easter, when Christ rose again from the dead. But the fact that so many different functions could be given to similar octagonal buildings also in a non-Christian context makes it difficult to believe that any symbolic meaning was given to the form itself and that this symbolism really was the reason behind the choice of the form.

Recent research tends to be more cautious. Discussing the question of symbolism in Early Christian architecture, Deichmann (Deichmann 1950; Deichmann 1983:89-108) expressed the conviction that the symbolic interpretation of these buildings which appears now and then in ancient texts, did not determine the shape of the building but was rather an interpretation of the building as it had been built for other purposes. More recently Jean Guyon (Guyon 2000:35f) discussed the shape of the monumental baptisteries of southern France, and concluded that any symbolic interpretation of these buildings was made only a posteriori. Most modern scholars generally agree that a symbolic and religious interpretation of the architecure of the Early Christian baptisteries was made only after the building had been built and did not influence its form.

Deichmann also believed that the liturgy contributed little to the shape of the buildings, and that the liturgy could be adapted to almost any kind of building. This last opinion seems, however, sligthly exaggerated. Surely there was some kind of relationship between the function of any ancient building and its shape. But the relationship between the actions performed in a building and the shape of the building must be discussed with more precision. Any action can be reduced to a basic, physical action - in the case of baptisteries, this action is the meeting between people and water. The meaning attributed to this action represents another level: Christian baptism was described already in the writings of the New testament as an imitation of death and burial (Rom 6) and a new birth to eternal life (John 3 ). But the fundamental action which was performed was still a rather normal bath. The shape of the building is certainly more determined by the basic level than by the secondary level of symbolic interpretation, which is usually expressed in decoration, mosaics, sculptures or inscriptions. For this reason it is no wonder that the shape of some of the most important, monumental, Early Christian baptisteries closely resembled some parts of the Roman baths, even if no symbolic allusion was intended. In the same way, they were also similar to other buildings with completely different functions but where the fundamental actions performed 
in the building presented the same structural challenges. In the language of Late Roman architecture, this shape was a rather standardized answer to the practical needs and challenges present in both baths and baptisteries and sometimes also in other kinds of buildings.

On the other hand, images and texts in the building help us to understand the meaning attributed to the action performed in the building and the symbolism of the water which was at the centre of that action. In this way, the building carried no symbolism in itself, but parts of its decoration underlined a symbolic interpretation of the actions performed in it. These general observations on the development of Early Christian architecture indicate that the key to understanding the meaning of the water in the baptistery must be sought in the decoration of the baptistery.

A good example of this is the decoration of the Lateran baptistery (Ristow 1998, no. 403-404; Brandt 1997-1998; Fig. 1). This baptistery was built by the emperor Constantine behind the apse of the Lateran basilica soon after the year 312. The basilica and baptistery were built together as the cathedral complex of Rome. Both the construction of the baptistery in the fourth century and its reconstruction a century later by Pope Sixtus III (432-440) are known not only from archaeology but also from the fifth-century Liber Pontificalis (LP I, 174f;

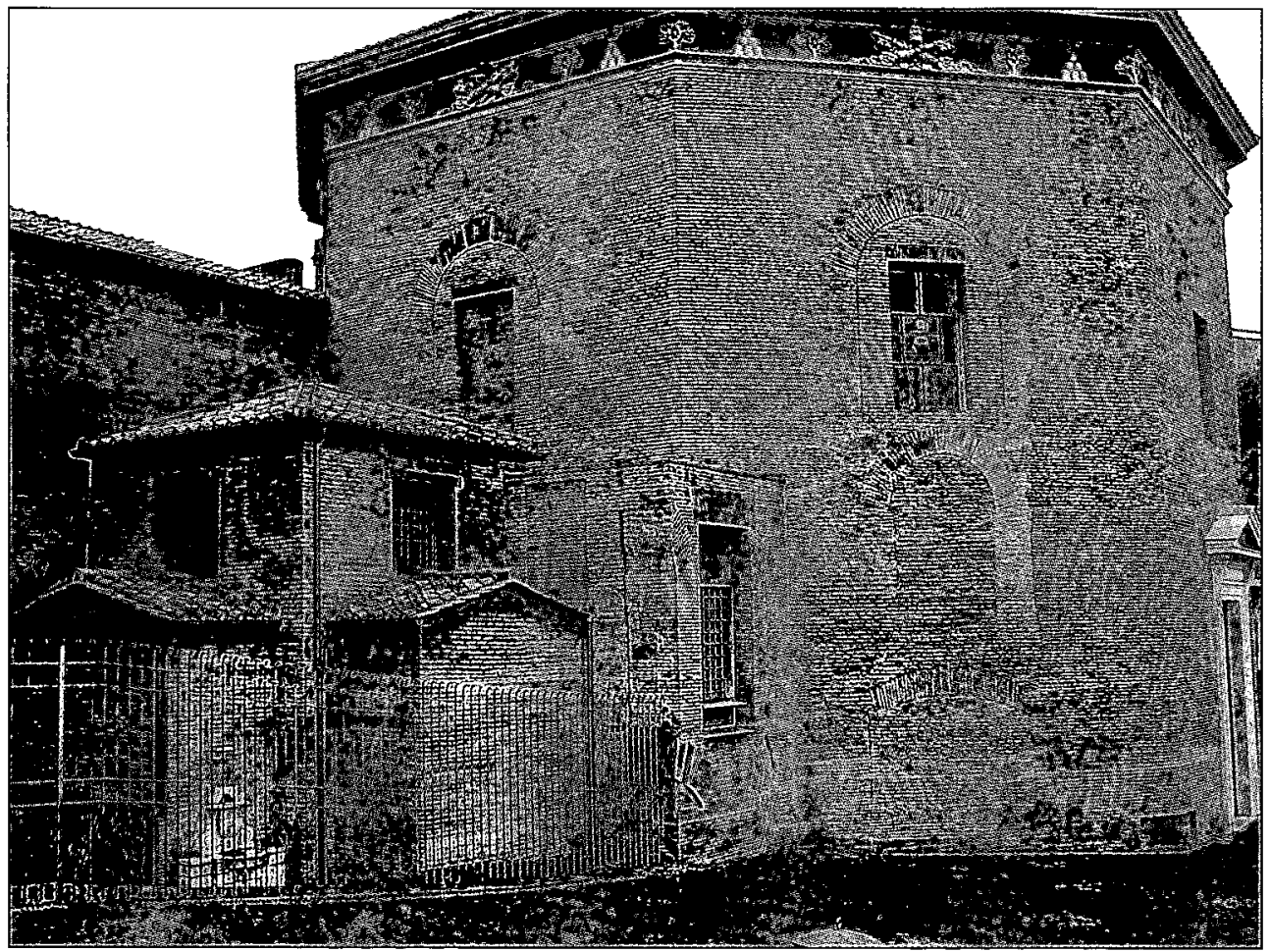

Fig. 1. The Lateran Baptistery (Rome) today. Photo by the author. 
234). The Lateran remained the centre of the Roman Church for a thousand years until the Popes moved to the Vatican, and the architecture and decoration of both the basilica and baptistery were important sources of inspiration for Early Christian architecture in the entire Late Roman world. This was probably the first monumental baptistery and thus occupies an important place in the development of this particular kind of Early Christian architecture.

The Lateran baptistery was the object of extensive excavations already in the 1920s (Giovenale 1929) and in the 1960s (Pelliccioni 1973), and recent studies have revealed that, contrary to earlier interpretations, the $19 \mathrm{~m}$ wide octagonal hall belongs to the first phase of the building (Brandt 1997-1998; Brandt 2001). There is still some uncertainty surrounding the question whether the building originally was covered by a dome or a wooden roof (Brandt 2000), but it is evident that the original Lateran baptistery was an octagonal hall, $19 \mathrm{~m}$ wide, with a large circular basin in the centre (Fig. 2). It is very remindful of bath architecture, from the calidarium in the third-century baths of Caracalla and the early fourth-century baths of Diocletian to the late second-century solarium in the Forum baths in Ostia (Nielsen 1990). The particular meaning attributed to the water in the basin was expressed in the first phase by a lavish decoration with silver and gold sculptures around the rim of the font, and in the second phase by an inscription on the baldacchino which was placed above the font in the reconstruction by Sixtus III (Fig. 3).

It can be of interest to describe what actually occured during the baptismal rite celebrated in the Lateran baptistery. The baptismal celebrations were held on only two occasions during the year: the solemn Vigils of Easter and of Pentecost, which concluded Easter. Obviously many persons were baptized each time, most of them adults. These celebrations were held at night, and one must imagine the huge hall lit by oil lamps. During the rite, water flowed down in the $10 \mathrm{~m}$ broad circular font from eight sculptures in silver and gold on its rim. A channel placed along the outside of the font collected the water from the feet of the newly baptized Christians (Pelliccioni 1973:57f, fig. 82). At the centre of the font, incense burned on top of a porphyry column (Cosentino 2001:532-534). The huge windows of the baptistery did not contribute to the illumination of the room during this nightly rite, but were rather illuminated themselves from the inside and may at the same time have created a rather suggestive impression from the outside, as has been suggested by Dale Kinney in her discussion of the origin of the church basilica (Kinney 2001:128f).

The silver sculptures of the first phase (Fig. 2) are only known from the sixthcentury collection of the lives of the Popes known as the Liber Pontificalis, which uses older archive documents in its detailed description of the building activities of the Popes during the fourth and fifth centuries (LP I, 174). According to this important text, the rim of the font was decorated with seven silver sculptures of deer which spouted water in the font, while an eighth group was made up of silvers sculptures of St. John the Baptist and Christ together with a smaller golden 


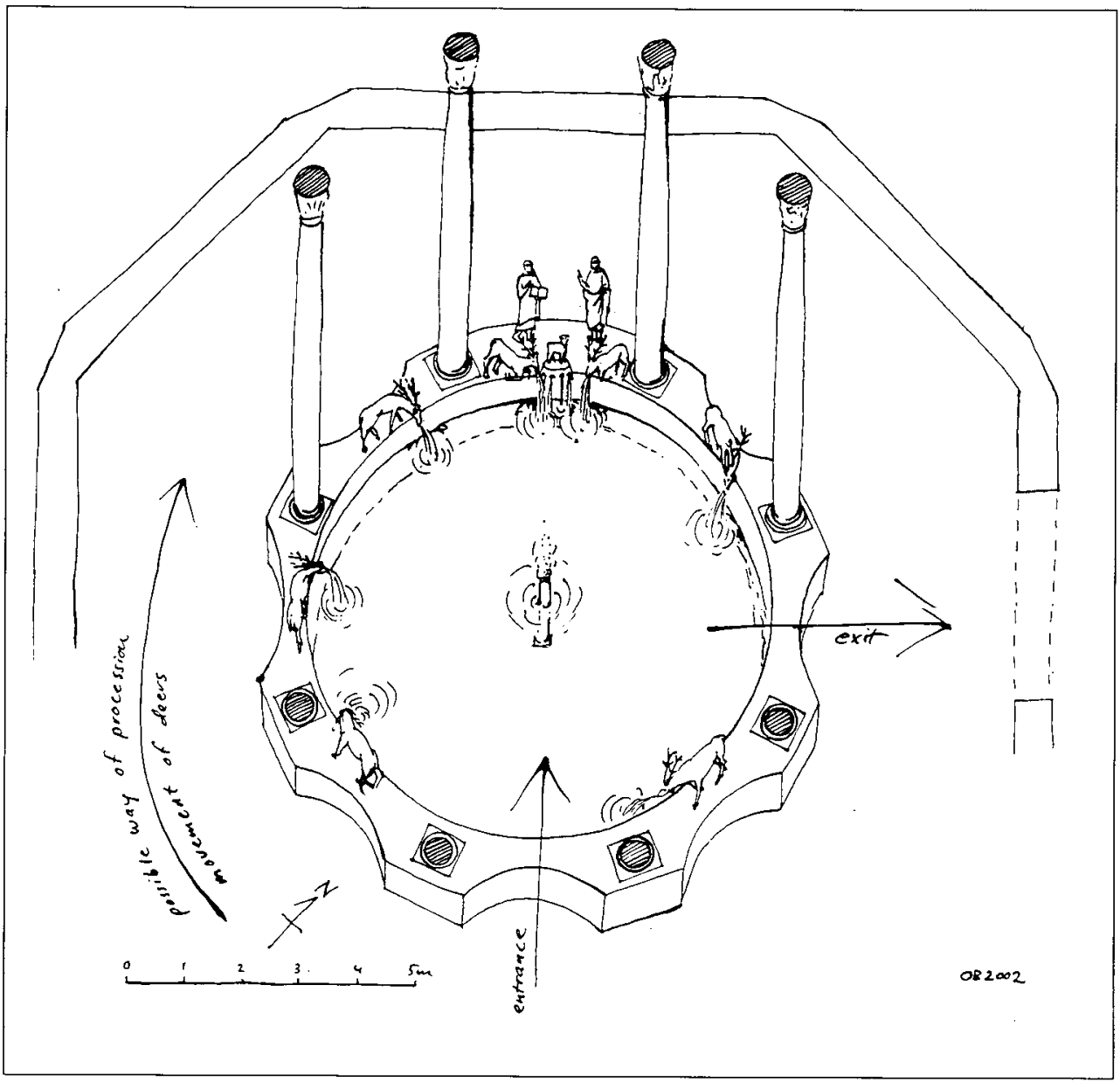

Fig. 2. The Lateran Baptistery (Rome): hypothetical reconstruction of the earliest phase of the decoration of the font inside the octagonal baptistery. As explained in the text, it is uncertain whether there were columns on the rim of the font already in the earliest phase, as supposed in this reconstruction. A reconstruction of the font without columns, as that I have published elsewhere (Brandt 1997-1998, Figs. 66-67), would however change only details in the understanding of the decoration of the font. Drawing by the author:

sculpture of the Lamb of God. The Liber Pontificalis also describes similar arrangements of silver deer in the early fifth century Roman baptisteries of San Vitale (LP I, 220) and Santa Maria Maggiore (LP I, 233), probably in both cases an imitation of the Lateran decoration. This arrangement of water-spouting sculptures shows that the love of "living water" was still strongly felt in the fourth century here in the Lateran, just as it was in other baptisteries such as the earliest baptistery of Milan, Santo Stefano, where the water entered the font at its bottom and bubbled up to the surface creating the effect of "living water" (Lusuardi Siena \& Sannazaro 2001:652). A similar effect must have been created in a later phase (after 512) of the same baptistery in Milan, when Ennodius described how 


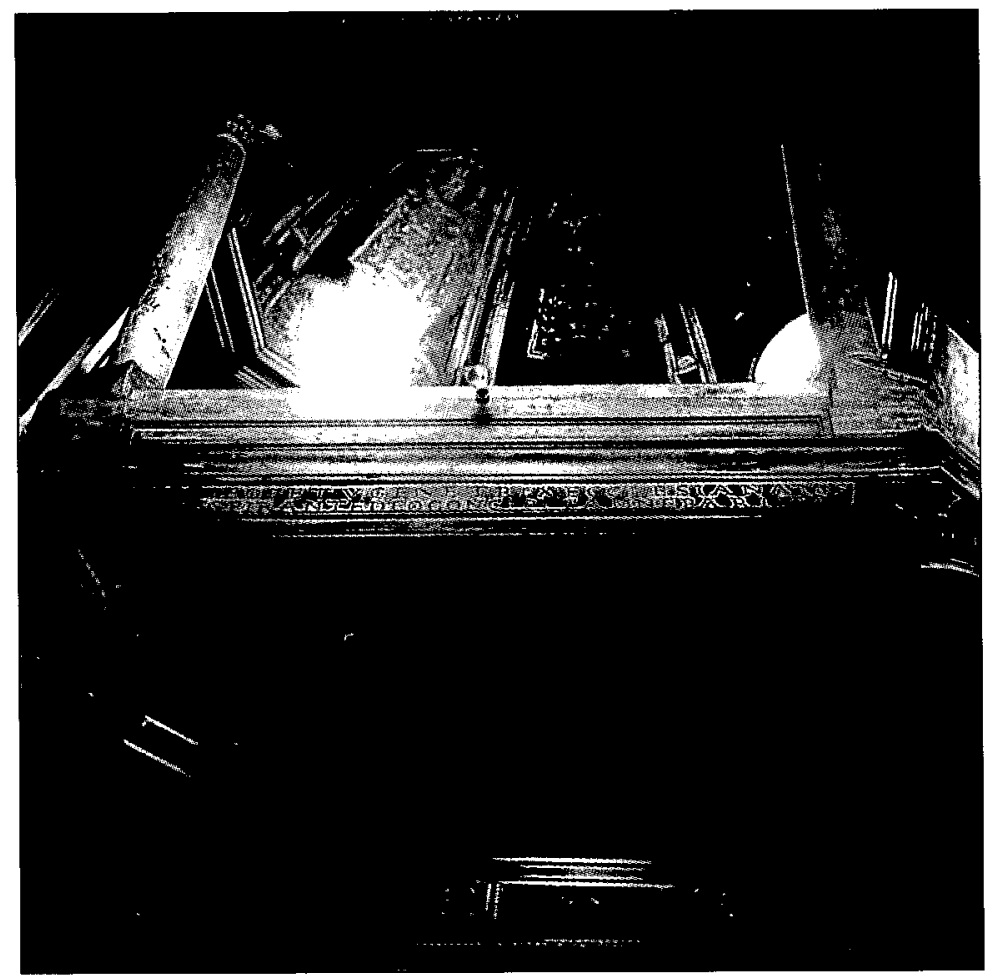

Fig. 3. The Lateran Baptistery (Rome): the baldacchino above the font and the inscription of Sixtus III. Photo by the author.

the water flowed down along eight columns in an arrangement which is very remindful of the eight water-spouting sculpture groups at the Lateran (Carm. 2, 149. In: MGH, AA, 7, 271).

It was thus a common desire in Late Antiquity to have running water in the baptismal font in order to create the effect of the "living water" of the Didaché. In the Lateran baptistery, one difficulty in reconstructing the exact arrangement of the water-spouting sculptures on the rim of the font is that it is far from certain how the first phase of the Lateran baptistery should be reconstructed. The font was circular internally but had eight external protuberances, creating a kind of star with eight points. Were the sculptures placed on these protuberances, where Sixtus III placed the eight columns which carry the baldacchino with his inscription? Or was there a similar arrangement with columns dividing the font from the circular passage around it already in the first phase? A discussion of this question has begun (Brandt 2000; Guidobaldi 2000:78) but more research is needed. This uncertainty naturally also creates problems for the understanding of the composition with the statues in silver and gold. I will discuss the details of this arrangement elsewhere, and concentrate here on what the decoration tells us about the symbolic value which this decoration attributed to the water in the font. 
It is evident from above that great importance was given to the scenographic presentation of the water in the baptistery. However, this scenography in itself meant nothing more than a well-made nymphaeum. The symbolic meaning attributed to the water in the baptistery was indicated by what the water-spouting sculptures represented. They alluded to biblical texts which were commonly used to explain the meaning of the water in the font and the baptism performed in it.

The statue of St. John the Baptist is a reminder of when John baptized Jesus through a Jewish ritual bath in what is interpreted as the moment when Jesus was anointed ("Christós") by the Spirit, manifested through a dove (Math 3:13-17; Marc 1:9-11; Luke 3:21-22; John 1:29-34); through baptism the Christian believer had God as his or her Father just as did Jesus, and received part of the Messianic mission of Christ as King, Prophet and Priest. According to the Liber Pontificalis, the sculpture of John the Baptist held an inscription with the words "Ecce Agnus Dei", "behold the Lamb of God", and the idea of the Lamb of God was illustrated also by a small, golden, water-pouring sculpture of a Lamb. The idea itself is closely related to the water of baptism: according to the Gospel of John, it is the expression used by John the Baptist about Jesus both before and after the baptism of Jesus (John 1:29 \& 36). John alluded to the lamb that was sacrificed at Easter, indicating that the waters of baptism were a tomb which prepared Jesus to become the sacrifical lamb, realizing with his death what had been only prefigured in the ritual sacrifice of a lamb at Easter. Christian writers from the second century onwards underline explicitly that Jesus is the sacrifical lamb of Passover, who takes upon him the sins of all (from Melito of Sardes, Peri Pascha "Homily on Easter", 65-67 (SC 123, 95-101; all the theological and patristical references can be found in Nikolasch 1963 and 1991).

The seven water-spouting deer along the rim of the font are remindful of the thirsty deer in psalm 42, whose thirst is a symbol of the thirst of the believer for the presence of God in the Temple of Jerusalem. The deer was known in the Mediterranean as a swift animal (Domagalski 1990), and a thirsty deer running to water is a poetic way of illustrating the urgency of the thirst. This psalm was used in the baptismal liturgy, and the water became a symbol of the presence of God, made accessible to all believers through the water of baptism. Perhaps the psalm about the deer running to water was illustrated physically through a solemn procession to the baptistery before the rite. Early Christian writers commenting upon psalm 42, in particular Ambrose, the bishop of Milan in the late fourth century, compared the thirst of the deer for water to the thirst of the believer for eternal life in baptism (Ambrose, In Ps 40,37. In: CSEL 64:255. Id., De interpellatione Iob et David 4(2),1,5. In: CSEL 32,2:271; see other references in Domagalski 1990).

The early fourth-century decoration of the first phase of the Lateran baptistery thus underlined the interpretation of the water of baptism as a tomb (the Lamb of God), where the believer was symbolically buried to be born again to a new life, the life of God, symbolized by the thirsty deer. 
A century later, Pope Sixtus III placed an inscription on the architrave of the baldacchino above the font (Fig. 3) which underlined a different interpretation of the water of baptism, as it describes in great detail the birth of the Christians in the water with words borrowed from sexuality.

The text is engraved on all eight sides of a marble architrave borne up by porphyry columns in a kind of octagonal baldacchino above the circular font at the center of the Lateran baptistery. The inscription and the entire baldacchino belong to the reconstruction of the fourth-century baptistery attributed to Pope Sixtus III (432-440) in the sixth-century Liber Pontificalis (LP I, 234). In 1930, F. J. Dölger (Dölger 1930) proposed that the text should be attributed to Pope Leo the Great, who was a deacon under his predecessor Sixtus III. Dölger presented no concrete proof for this "hypothesis", as it was defined by Charles Pietri (Pietri 1976:510-511), but only the general similarity between the ideas expressed in the inscription and the writings of Leo the Great. Later, P. A. Underwood accepted this attribution (Underwood 1950). The inscription has recently been commented upon briefly by Giuseppe Cuscito (Cuscito 2001:443-445). The text is usually cited from the medieval transcription published by Giovanni Battista de Rossi in his late $19^{\text {th }}$-century edition of Early Christian inscriptions from Rome (de Rossi 1888:424, repeated in Diehl 1925 No. 1513). The spelling of the actual inscription, which is given below is, however, slightly different from the medieval transcriptions (fetu instead of faetu). As a matter of fact, because of the well-known edition of the medieval transcription, the actual inscription has never been published as such.

Gens sacranda polis hic semine nascitur almo

quam fecundatis Spiritus edit aquis.

Mergere peccator sacro purgante fluento

quem veterem accipiet proferet unda novum.

Nulla rinascentum est distantia quos facit unum

unus Fons unus Spiritus una Fides.

Virgineo fetu genetrix ecclesia natos,

quos spirante Deo concipit, amne parit.

Insons esse volens isto mundare lavacro

seu patrio premeris crimine seu proprio.

Fons hic est vitae qui totum diluit orbem, sumens de Christi vulnere principium.

Caelorum regnum sperate hoc fonte renati non recipit felix vita semel genitos.

$\mathrm{Nec}$ numerus quemquam scelerum nec forma suorum terreat hoc natus flumine sanctus erit.

(An offspring that will be sacred for heaven is born here, through lifegiving seed, an offspring which the Spirit gives life to after having made the water fertile. 
Sinner, let yourself be immersed into the holy purifying stream; whom the waves will receive old they will bring forth new.

There is no distinction between those who are reborn, since one Fount, one Spirit, one Faith make them one.

Through virginal birth mother Church gives life in the stream to the children that she conceives through the breath of God.

If you wish to be freed from your sins, purge yourself in this bath, whether it is the original sin or your personal sins that torment you.

Here is the spring of life, which purges the whole world, originating in the wound of Christ.

Hope for the realm of heaven, you who are reborn in this font; the blessed life does not receive those who were born only once

May no one be frightened by the number or the character of his sins: one who is born through this river will be holy.)

(Translation by G. Vidén)

It is evident that water is at the centre of this long and articulated text. The people of God are born in the water made fecond by the Spirit. The Church, understood as a female spiritual reality made up of the part of mankind which is united with God through Christ, gives birth to new children of God in the stream. The birth, of course, is a birth to eternal life: the water is described as the source of life which originates in the wounds of Christ. The text also stresses that the water of baptism, described as a holy purifying stream, purifies all sins.

In a later source, the idea of the fecondity of the water of baptism was expressed in a Roman prayer for baptism, which compares the font to a womb, namely in the Sacramentarium gelasianum, one of the most important sources of knowledge about the liturgy of Rome. It is known to us from a manuscript from around 750 but may have been written already in the fifth century. The Roman origin of the prayer makes it probable that it was used in the Lateran baptistery, offering a rare opportunity to combine texts and monuments in our reconstruction of the original understanding of an ancient building and the actions performed in it. Before the celebration of the baptismal rite, the water in the font was blessed through a prayer to the Father to send his Spirit:

Qui hanc aquam regenerandis hominibus praeparatum archano sui luminis admixtione fecundet, ut sanctificatione concepta ab immaculato divini fontis utero in novam renatam creaturam progenies caelestis emergat (In: Mohlberg 1960:73; also in Chavasse 1997:114; see also the study by Chavasse 1958) .

(Let the Holy Spirit, by the hidden admixture of his light, give fruitfulness to this water prepared for the rebirth of humankind, that, with sanctification conceived in it, a heavenly offspring may come forth from the virginal womb of the divine font.) 
Fundamentally both the sculptures and the inscriptions in the Lateran baptistery, together with the prayers which were probably used in this building, show that water was simultaneously seen as a symbol of both life and death: the death of the old, sinful man, and the life of God to which the believer gained access through baptism.

Several factors contributed to the importance of the decoration which expressed the symbolic interpretation of the water in the baptisteries. To begin with, the first monumental baptisteries were created during a period of great interest in water architecture. The fourth and fifth centuries were also a time when the Christian Church could see the baptisteries as monuments celebrating the conversion of the masses and thus the triumph of the Church, and it was natural to assign great importance to the architecture and decoration of the baptisteries. Another important factor was, of course, the frequency of baptism of adults in a period when Christianity was still expanding and most of the converts were adults. This made it possible to prepare adult candidates for baptism with teaching in which the richness of the biblical texts and of Late Antique theological speculation were comprehended by the persons who were preparing themselves for baptism or studied later for deeper meaning after the rite. This is shown by the 23 catecheses of Cyrillus of Jerusalem, of which 18 were pronounced before baptism (in: PG 33) and five, the so-called mystagogic catecheses, after baptism (in: SC 126). It was quite natural that much of this rich symbolism was forgotten when the baptism of children became more common, and consequently a theological preparation of the candidates more difficult.

English revised by Laura Wrang.

\section{ABBREVIATIONS}

CSEL $=$ Corpus Scriptorum Ecclesiasticorum Latinorum. Vindobonae.

ILCV = Inscriptiones Latinae Christinae veteres, ed. E. Diehl. Berolini, I 1925, II 1927, III 1931.

LP $=$ Le Liber Pontificalis. Texte, introduction et commentaire per l'abbé L.

Duchesne, I. Paris 1886.

MGH, AA = Monumenta Germaniae Historica. Auctores Antiquissimi. Berolini. $\mathrm{PG}=$ Patrologiae cursus completus, series Graeca, accurante J.-P. Migne, Parisiis. $\mathrm{PL}=$ Patrologiae cursus completus, series Latina, accurante J.-P. Migne, Parisiis. $\mathrm{SC}=$ Sources chrétiennes. Paris. 


\section{REFERENCES}

Brandt, O. 1997-1998. Il battistero lateranense da Costantino a Ilaro. Un riesame degli scavi. Opuscula Romana. Annual of the Swedish Institute in Rome. Vol. 22-23. Pp. 7-65.

- 2000. Ipotesi sulla struttura del battistero lateranense tra Costantino e Sisto III. Acts from "Ecclesiae urbis - congresso internazionale sulle chiese di Roma (IV-X secolo)", Rome, September 2000 (not yet published)

- 2001. Il battistero lateranense dell'imperatore Costantino e l'architettura contemporanea: Come si crea un'architettura battesimale cristiana?. In: J. Fleischer, J. Lund \& M. Nielsen (Eds). Late Antiquity. Art in context. (Acta Hyperborea 8). Pp. 117-144. Copenhagen.

Chavasse, A. 1958. Le sacramentiare gélasien (Vaticamus Reginensis 316). Sacramentaire presbytéral en usage dans les titres romains au VIIe siècle. Tournai.

- 1997. Textes liturgiques de l'Église de Rome. Le cycle liturgique romain anmuel selon le sacramentaire du Vaticanus Reginensis 316 (Sources liturgiques 2). Paris.

Cosentino, A. 2001. Il fuoco sul Giordano, il cero pasquale, la columna del battistero lateranense. L'edificio battesimale in Italia. Aspetti e problemi. Atti dell'VIII Congresso Nazionale di Archeologia Cristiana. Genova, Sarzana, Albenga, Finale Ligure, Ventimiglia 21-26 settembre 1998. Pp. 521-540. Bordighera.

Cuscito, G. 2001, Epigrafi di apparato nei battisteri paleocristiani d'Italia. L'edificio battesimale in Italia. Aspetti e problemi. Atti dell'VIII Congresso Nazionale di Archeologia Cristiana. Genova, Sarzana. Albenga, Finale Ligure, Ventimiglia 21-26 settembre 1998. Pp. 440-466. Bordighera.

Deichmann, F. W. 1983. Einfïhrung in die christliche Archäologie. Darmstadt.

- 1950. Baptisterium. Reallexikon für Antike und Christentum I. Coll. 1157-67.

de Rossi, G. B. 1888. Inscriptiones Christianae urbis Romae septimo saeculo antiquiores. II. Romae.

Diehl, E. 1925. Inscriptiones Latinae Christianae veteres. I. Berolini.

Domagalski, B. 1990. Der Hirsch in spätantiker Literatur und Kunst unter besonderer Beriücksichtigung der frühchristlichen Zeugnisse. (Jahrbuch für Antike und Christentum. Ergänzungsband 15). Münster.

Dura 1967. Dura Europos Final Report VIII, 2. The Christian Building. New Haven.

Dölger, F. J. 1930. Die Inschrift im Baptisterium S. Giovanni in Fonte an der Lateranensischen Basilika aus der Zeit Xystus' III (432-440) und die Symbolik des Taufbrunnens bei Leo dem Grossen. Antike und Christentum. Kultur-und Religionsgeschichtliche Studien. Vol. 2. Pp. 252-257. München in Westfalen.

Farrar, L. 1996. Gardens of Italy and the Western Provinces of the Roman Empire $4^{\text {th }}$ century $B C-4^{\text {th }}$ century $A D$. Oxford.

Finn, Th. M. 1992. Early Christian baptism and the cathechumenate. Message of the Fathers of the Church 6. Collegeville, Minnesota.

Giovenale, G. B. 1929. Il battistero lateranense nelle recenti indagini della Pontificia commissione di archeologia sacra. (Studi di antichità cristiana l). Roma.

Guidobaldi, F. 2000. La basilica lateranense. In: L. Pani Ermini. (Ed). La visita alle 'Sette chiese'. Pp. 69-89. Roma.

Guyon, J. 2000. Les premiers baptistères des Gaules (IVe-VIIIe siècles). (Unione internazionale degli istituti di archeologia storia e storia dell'arte in Roma. Conferenze, 17). Roma.

Katchatrian, A. 1980. $2^{\text {nd }}$ ed. Les baptistères paléochrétiens. Paris.

Kinney, D. 2001. The church basilica. Imperial art as Christian art-Christian art as Imperial art. Expression and meaning in art and architecture from Constantine to Justinian. (Acta ad archaeologiam et artium historiam pertinentia. Vol. 15). 115-135.

Klauser, Th. 1939. Taufet in lebendigem Wasser! Studien zur Religion und Kultur des Altertums Franz Joseph Dölger zum sechzigsten Geburtstage dargeboten. Pp. 157-64. Münster in Westfalen.

Lusuardi Siena, S. \& Sannazaro, 2001. M. I battisteri del complesso episcopale milanese alla luce delle recenti indagini archeologiche. L'edificio battesimale in Italia. Aspetti e problemi. Atti dell'VIII Congresso Nazionale di Archeologia Cristiana. Genova, Sarzana, Albenga, Finale Ligure, Ventimiglia 21-26 settembre 1998. Pp. 647-674. Bordighera. 
Mohlberg, L. C. 1960. Liber sacramentorum Romanae aeclesiae ordinis anni circuli (Cod. Vat. Reg. lat. 316/Paris Bibl. Nat. 7193, 41/56) (Sacramentarium Gelasianum). (Rerum ecclesiasticarum documenta cura Pontificii Athenaei Sancti Anselmi de Urbe edita moderante L. C. Mohlberg. Series Maior. Fontes 4). Roma.

Neuerburg, N. 1960. L'architettura delle fontane e dei ninfei nell'Italia antica. Napoli.

Nielsen, I. 1990. Thermae et balnea. Aarhus.

Nikolasch, F. 1963. Das Lamm als Christussymbol in der Schrifter der Väter:

Nikolasch, F. 1991. Agnello. Enciclopedia dell'arte medievale I. Pp. 220-225. Roma

Pelliccioni, G. 1973. Le nuove scoperte sulle origini del battistero lateranense. (Atti della Pontificia Accademia Romana di Archeoologia. Memorie 12, 1). Città del Vaticano.

Pietri, Ch. 1976. Roma Christiana. Recherches sur l'Eglise di Rome, son organisation, sa politique, son idéologie de Miltiade à Sixte III (3/I-440). Bibliothèque des Écoles Francaises d'Athènes et de Rome 224. Rome.

Ristow, S. 1998. Frühchristliche Baptisterien. (Jahrbuch fur Antike und Christentum. Ergänzungsband 27). Münster.

Saxer, V. 1988. Les rites de l'initiation chrétienne du Ile au Vle siècle. Spoleto.

- 1998. La Didachè. Miroir de communautées chrétiennes du Ier siéecle. Domum tuam dilexi. Miscellanea in onore di Aldo Nestori. (Studi di antichità cristiana pubblicati a cura del Pontificio Istituto di Archeologia Cristiana 53). Pp. 771-798. Città del Vaticano.

Styger, P. 1933. Nymphäen, Mausoleen, Baptisterien; Probleme der Architekturgeschichte. Architectura. Vol. 1. Berlin.

Underwood, P. A. 1950. The fountain of life. In: Dumbarton Oak Papers. Vol. 5. Pp. 41-138. 